\title{
A Presidência do Congresso Nacional na Constituição de 1967.
}

\author{
Miguel Reale \\ Catedrático de Filosofia do Direito na Facul- \\ dade de Direito da Universidade de São Paulo.
}

I.

Colocação do problema.

1. Não é novidade entre os mestres do Direito pátrio o princípio de que, sendo a Constituição um sistema de normas, cuja validade implica a sua necessária coerência lógica, nenhum de seus preceitos é suscetível de ser interpretado isoladamente, sem correlações com os dispositivos todos que albergam o seu rigoroso sentido.

É que tôda Constituição, como instrumento fundamental da vida social e política de um povo, consubstancia determinadas diretrizes ideais, assim como elege e consagra definidas técnicas de govêrno, resultando dêsses pressupostos estruturais o verdadeiro alcance, assim como os limites dos dispositivos que a integram.

Rui Barbosa soube dar-nos, magistralmente, a razão da unidade sistemática substancial dos textos constitucionais, ao escrever:

“As Constituições não são regulamentos administrativos, não são tratados casuísticos, não são roteiros de precauções meticulosas contra a chicana, a ignorância, ou a subserviência mental da rabulice interessada, ou míope. Uma Constituição é a caracterização, nìtidamente contornada, de um sistema político, indicado nas suas linhas capitais, 
entregue, na evolução da sua vida orgânica, à ação da consciência popular, confiado, na interpretação das suas conseqüências legislativas, à intuição dos homens de estado. A evidência das regras diretrizes, a luz do alto que desce dos princípios, ilumina os casos particulares, ditando, a cada ocorrência imprevista, a cada combinação dos fatos, a solução definida pelas necessidades da harmonia geral". (Rui Barbosa, Discurso no Senado Federal, a 3 de julho de 1891; nos Comentários à Constituição Federal Brasileira, coligidos e ordenados por Homero Pires, 1932, I v., p. 38).

Essa exigência de unidade coerente Rui estendia-a, aliás, a tôda a ordem jurídica, que deve, efetivamente, ser compreendida como um lucidus ordo, no qual cada elemento possui um lugar definido e não pode ter outro, de modo que a interpretação lógica se revela, concomitantemente, sistemática.

E a razão pela qual o patrono dos constitucionalistas brasileiros advertia:

“... a ligação (da matéria nos textos legislativos) não há de ser meramente a vizinhança material entre as linhas do mesmo texto. Ela não se concebe sem a consentaneidade lógica entre os dois pensamentos que a contigüidade literal aproximou. Nunca se cogitou, portanto, de mera confinidade material dos diversos parágrafos da lei". (Anistia Inversa, Rio de Janeiro, 1896, Prefácio).

Nesses ensinamentos se contêm duas regras essenciais, sobretudo na tela da hermenêutica constitucional: o dever que tem o exegeta de interpretar cada artigo ou cada parágrafo em sua situação peculiar, ou, como se volta a dizer hoje, em sua significação tópica (Cfr. VIEHweg TH. Topica e Giurisprudenza, trad. de G. Grifó, Milão, 1962) e, 
ao mesmo tempo, o dever não menos indeclinável de correlacioná-lo com os demais dispositivos, integrando-o em sistema.

A nenhum jurista de tomo, antes mesmo da triunfante e avassaladora compreensão do Direito como "realidade concreta e dinâmica", que caracteriza a Jurisprudência contemporânea, escapou o apontado sentido das correlações normativas, bastando lembrar aqui o pensamento lapidar e audacioso de Teixeira de Freitas, de uma atualidade impressionante:

"... o sistema inteiro de um código depende muitas vêzes de uma só disposição". (Consolidação das Leis Civis, $3 .^{\mathrm{a}}$ ed., Rio de Janeiro, p. LIX).

É na linha dessa alta tradição que o eminente Ministro Prado Kelly escreve:

“... a Constituição não é um documento parcialmente obrigatório; é um ato solene da vontade nacional; não pode ser obedecida em várias de suas normas e negada em muitos de seus preceitos". (Estudos de Ciência Politica, São Paulo, 1966, t. III, p. 8).

Tal atitude pressupõe, é claro, o que E. Garcia Maynez denomina "princípio da interpretação contextual", a cuja luz se atende às exigências lógicas impostas "pela tendência sistemática dos ordenamentos", isto é, pela compreensão dos preceitos jurídicos como partes ou elementos de um todo orgânico (Cfr. Lógica del Raciocinio Jurídico, México, 1964, p. 31 e segs.).

2. Relembradas essas diretrizes fundamentais, que correspondem ao que há de mais atual e vivo em matéria de Hermenêutica Jurídica, claro está que não se pode responder à Consulta formulada, sôbre a extensão do dispositivo constitucional que confere ao Vice-Presidente da República o exercício das funções de Presidente do Con- 
gresso Nacional, com esta singela e sumária conclusão: "se o art. 79, $\$ 2 .^{\circ}$, reza que o Vice-Presidente exercerá as funções de Presidente do Congresso Nacional, tendo sòmente voto de qualidade, a êle caberá sempre presidir às sessões conjuntas da Câmara dos Deputados e do Senado, qualquer que seja o motivo da convocação".

Essa interpretação fragmentada ou atomizante, sôbre desatender aos critérios já lembrados de unidade sistemática, deixa-nos no limiar do processo interpretativo, nas dobras do que se convencionou denominar "interpretação gramatical".

Não é necessário invocar autores para se demonstrar o caráter preparatório ou vestibular dêsse tipo de exegese. Inexistente, na realidade, uma "interpretação gramatical" por si bastante, como é impróprio falar-se em "interpretação lógica", "interpretação sistemática", etc., como algo de fracionado e de autônomo: são antes momentos ou elementos componentes do processo interpretativo, o qual não pode; em caso algum, deixar de ser unitário e coerente.

Ora, o elemento filológico, embora sendo ponto de partida inamovível na tarefa compreensiva das normas de Direito, deve ser recebido com cautela, pois, como lembra Françors GenY, a mera conceitualização "acaba por sacrificar as realidades morais, econômicas, sociais, que constituem o fundo material e como que o conteúdo efetivo da vida jurídica, a sinais, puramente lógicos, que da mesma não revelam senão um aspecto de todo formal". (Science et Technique en Droit Privé Positif, Paris, 1922, v. I, p. 149).

Daí as palavras incisivas de Carlos MaXimiliano, encerrando suas indagações sôbre a matéria:

“Emm conclusão, nunca será demais insistir sôbre a crescente desvalia do processo filológico, incomparàvelmente inferior ao sistemático, e ao que invoca os fatôres sociais, ou o Direito Comparado. Sôbre o pórtico dos tribunais cumpria ins- 
crever o aforismo de Celso: Scire leges non hoc est verba earum tenere, sed vim ac potestatem". (D.L. 1, 3, 17. Celsus; Maximiliano - Hermenêutica e Aplicaçâo do Direito, Pôrto Alegre, 1933, p. 136).

E a razão pela qual a doutrina atual condena, de maneira veemente, o que o ilustre EMílı BETTI denomina "o modo de ver mecânico e atomístico, que desintegra as fases sucessivas do processo interpretativo, tratando-as como se fôssem meios distintos, suscetíveis de serem empregados de maneira indiferente, segundo as contingências e as oportunidades". Contra essa fragmentação da exegese, que chega ao absurdo de se contentar com o momento liminar da explicação verbal, invoca o mestre de Roma a unidade integrante e incindivel do processo de compreensão da norma, mostrando que, além do elemento verbal e do conteúdo lógico da fórmula legislativa, deve indagar-se de ratio juris que é a sua substância valorativa e teleológica. (E. BETTI - Interpretazione della legge e degli atti giuridici, Milão, 1949, p. 168 e 174).

3. Tal compreensão da matéria, válida para todos os campos do Direito, adquire uma relevância maior nos domínios do Direito Constitucional, que, por sua natureza, implica cânones e critérios interpretativos, em consonância com os valores políticos que o informam e, de maneira constante e direta, o potenciam.

Veremos, logo mais, como o problema objeto da presente Consulta adquire contornos precisos e como que se ilumina em função do "espírito da Constituição" de 1967, ou seja, quando pôsto nas coordenadas do processo legislativo que nela se consagra, em virtude de uma nova compreensão do princípio da divisão dos poderes e da distribuição das competências.

É que, em verdade, os elementos gramatical, lógico e sistemático, na exegese constitucional, só adquirem autên- 
tico significado na medida e enquanto se subordinam a um centro ideológico ou doutrinário, que é o "foco doador de sentido" às regras do ordenamento, por ser a fôrça intrínseca que vincula e estrutura o todo e nele situa orgânicamente as partes componentes.

A teoria da interpretação é, sem dúvida, una e concreta, mas exatamente porque tôda regra jurídica é a prefiguração de uma classe de ações possíveis, o exegeta não pode deixar de correlacionar o "esquema normativo" ao seu "âmbito de eficácia" ou "possibilidade", o que envolve uma natural discriminação entre os critérios interpretativos aplicáveis neste ou naquele outro campo do Direito.

No tocante à interpretação das normas de Direito Constitucional, sobretudo, aduzem os tratadistas algumas peculiaridades que o monografista Carmelo Carbone põe em realce, em função do caráter primordial $e$ eminente das normas constitucionais, da natureza esquemática de seu conteúdo e de sua íntima conexão com o regime político, aspecto êste apontado como o mais saliente (Cfr. CARbone, Interpretazione delle norme costituzionali, Pádua, 1951).

Veremos como, no caso em aprêço, foi exatamente êsse elemento essencial e decisivo que foi inteiramente desprezado pelos autores do projeto de resolução tendente a reformar o Regimento Comum do Congresso Nacional.

II.

Os artigos $31, \S 2 .^{\circ}$, e $79, \S 2 .^{\circ}$, no sistema da Constituição de 1967.

4. Nada, pois, mais absurdo do que uma interpretação dos artigos supra referidos lançando-se mão de um artifício consistente em emprestar validade a um dispositivo, à custa do esvaziamento do outro, quando, na realidade, o problema consiste em saber-se que entendimento 
válido se há de dar ao $\S 2 .^{\circ}$ do art. 79 - para que êsse dispositivo não fique sem efeito -, mas de maneira tal que também não resulte sem efeito o $\S 2 .^{\circ}$ do art. 31. que diz:

$$
\begin{aligned}
& \text { “Art. } 31-\ldots \ldots \ldots \ldots \ldots \ldots \ldots \ldots \ldots \ldots \ldots \ldots \ldots \\
& \S 2 .^{\circ} \text { - A Câmara dos Deputados e o Senado, sob } \\
& \text { a direção da Mesa dêste, reunir-se-ão em sessão } \\
& \text { conjunta para: } \\
& \text { I - inaugurar a sessão legislativa; } \\
& \text { II - elaborar o regimento comum; } \\
& \text { III - receber o compromisso do Presidente e do } \\
& \text { IV - deliberar sôbre veto; } \\
& \text { V - atender aos demais casos previstos nesta } \\
& \quad \text { Constituição". }
\end{aligned}
$$

Atendendo à primeira das duas regras de hermenêutica anteriormente discriminadas, relativa à situação ou à tópica das regras de direito, cabem desde logo as seguintes observações :

a) o $\S 2 .^{\circ}$ do art. 31 se inscreve num artigo cujo objetivo é disciplinar as reuniões do Congresso Nacional, tanto as ordinárias como as extraordinárias;

b) $0 \S 2 .^{\circ}$ dêsse dispositivo declara como devem ser obrigatòriamente dirigidos os trabalhos do Congresso nas hipóteses que enumera taxativamente;

c) o art. $79, \S 2 .^{\circ}$, enuncia genèricamente a competência do Vice-Presidente da República para exercício da presidência do Congresso;

d) tal dispositivo de caráter genérico surge, pois, com o seu âmbito de incidência delimitada pela atribuição específica constante do art. 31. 
Pode-se, por conseguinte, afirmar que o legislador constituinte, ao dispor sôbre as reuniões do Congresso Nacional, destacou aquelas que, por sua natureza ou deslinação, entendeu deverem ser dirigidas pela Mesa do Senado Federal, ficando reservadas as demais sessões à presidência do Vice-Presidente da República.

Nada dispondo a Constituição sôbre a composição da Mesa do Congresso, quando competir ao Vice-Presidente a função de dirigir os trabalhos, estamos perante uma lacuna, que poderá ser preenchida por disposição regulamentar do Congresso, mas não de modo a tornar sem efeito o $\S 2 .^{\circ}$ do art. 31, isto é, subtraindo ao Presidente do Senado a presidência e direção das sessões conjuntas, nos casos que aquêle parágrafo taxativa e especificamente determina.

Ora, a solução constante do Projeto de Resolução que visa modificar o Regimento Comum do Congresso Nacional, congregando os dois artigos aqui examinados, a fim de outorgar ao Vice-Presidente a "presidência" das sessões e à Mesa do Senado a sua "direção", não resiste à mais perfunctória análise, a começar pelo exame dos aspectos gramaticais até às razões lógicas e teleológico-políticas das duas normas constitucionais, aparentemente em conflito.

A distinção entre "presidir" e "dirigir" o Congresso não encontra guarida sequer no plano liminar da exegese gramatical, como o demonstram os mestres da língua.

Leia-se, por exemplo, como que prevendo e prevenindo o artifício curioso que ora nos surpreende, o que ensina Caldas Aulete:

"Presidir, v. tr. dirigir como presidente; presidir o congresso (com complemento direto). Exercer funções próprias de quem dirige os trabalhos ou as sessões de uma assembléia". (Dicionário contemporâneo da língua portuguêsa, ed. bras., Rio de Janeiro, 1958).

Da mesma forma, consigna Laudelino Freire que presidir significa: 
1. Assistir como presidente ou árbitro (...).

2. Ocupar o primeiro lugar em uma assembléia com direito de manter a ordem e regular a discussão; exercer as f unções de presidente (. .).

3. Guiar como chefe; dirigir, comandar (...).

4. Superintender (...).

5. Ter a principal influência ou o principal papel; dirigir, guiar, amparar etc.

Não creio seja necessário trazer outros esclarecimentos, tão transparente me parece a impossibilidade de se cometer a um órgão a função de presidir e a outro a de dirigir o Congresso Nacional, num dualismo incompativel, quer do ponto de vista lógico, quer do ponto de vista prático, com a essencial unidade de direção requerida pelas atividades de uma assembléia.

5. Tal dualismo aberrante, que começa por entrar em choque com as palavras, implica, desde logo, outra conseqüência bem mais grave, consistente na desfiguração do conceito jurídico de "Mesa do Senado", que sofre dois impactos :

a) primeiro porque é ela desintegrada, cedendo o seu Presidente o lugar que lhe é próprio - ex vi dos votos conferidos por seus pares - ao Vice-Presidente da República;

b) em segundo lugar, porque é ela rebaixada de sua posição eminente, deixando de dirigirpresidindo as sessões, para passar a dirigirassessorando - digamos assim, pois a tanto equivale o verbo dirigir, por eufemismo empregado no art. $3 .^{\circ}$ do projeto de resolução -, subordinada, pois, à segunda autoridade do Poder Executivo. 
Não é mister tecer longas considerações sôbre o conceito de Mesa do Senado para dever-se reconhecer que ela só pode ser entendida como um todo indecomponível, no qual as competências de seus membros componentes se articulam e se escalonam, tendo como ápice a figura de seu Presidente. É ela não apenas parte integrante do Senado mas seu elemento constitutivo, como seu órgão próprio e indeformável, aquêle através do qual a Câmara Alta se manifesta na plenitude de suas prerrogativas. Invocando um antigo preceito do regulamento do Senado francês, assim adverte Duguit, pondo em realce o valor constitutivo do órgão dirigente de uma Assembléia Parlamentar :

"Ce n'est que du moment où le bureau definitif est formé que l'assemblée est constituée". (Traité de Droit Constitutionnel, 2. ${ }^{\mathrm{a}}$ ed., Paris, 1924, t. IV, p. 265).

Não se compreende, pois, como a Mesa do Senado, constituída ex vi do art. 31 , $33^{\circ}$, da Constituição, passe a ter os seus membros e as suas atribuições alterados em virtude de mera reforma do regimento comum do Congresso, a fim de ser convertida em órgão assessor do VicePresidente da República, a quem é conferida a presidência de tôdas as sessões conjuntas, abstração feita dos objetivos destas.

Dá-se, com essa intromissão indébita de uma autoridade do Executivo na órbita do Poder Legislativo - para exercício de funções claramente conferidas à Mesa do Senado -, manifesta ofensa ao princípio da divisão dos poderes, pois até mesmo autores que fazem fortes reservas à latitude dêsse princípio não podem deixar de reconhecer que as exceções às distintas esferas de competência dos órgãos soberanos do Estado

"debbono risultare stabilite in maniera diretta o derivata dalla stessa costituzione" (ANTonio AMorTh, 
em artigo na Riv. Trimestrale di Diritto Pubblico, 1958, v. VIII, p. 63).

Na mesma ordem de idéias, Emilıo Crosa, acentuando a correlação que necessàriamente deve existir entre a com-petência constitucional e o poder de auto-organização, exclui a possibilidade de qualquer interferência externa, ou verbis:

"L'attribuzione costituzionale di competenza implica la potestà di esercitare i propri uffici, salvo il coordinamento per ciò che ne riguarda l'inizio o la fine, regolati pur essi dalla costituzione, escludendo l'intervento di qualsiasi altro organo nell'esercizio di tali funzioni poichè questo trarrebbe tale sua competenza da una fonte subordinata alla norma costituzionale e pertanto illegittima ed anche superflua. ("Gli organi costituzionali e il Presidente della Republica nella costituzione italiana", in Rivista Trimestrale di Diritto Pubblico, 1951, p. 94).

6. Parece-me que o êrro central na interpretação dos artigos $31, \S 2 .^{\circ}$, e $79, \S 2 .^{\circ}$, resulta do fato de não se atentar que temos em confronto, como já notei, dois preceitos: o primeiro específico; o segundo genérico.

Mister é, por conseguinte, não juntá-los mecânicamente, numa justaposição forçada de proposições normativas - cada qual sendo, como é, dotada de eficácia autônoma -, mas sim fixar o âmbito de validade de cada uma delas, de sorte que ambas signifiquem, concomitantemente, algo de eficaz no contexto do ordenamento.

Quando o legislador dispõe sôbre o mesmo assunto, mas fazendo-o de dois modos, atribuindo, genèricamente, competência a determinado órgão para o exercício de certas funções, e, ao mesmo tempo, conferindo a outro a prática de atos que, em tese, se conteriam no primeiro 
enunciado normativo, cumpre indagar da "mens legis", da razão determinante dos dois preceitos, a fim de se resolver a aparente contradição num claro discrime de duas faixas de vigência e efetividade.

Há em tal caso, dois caminhos absurdos e intoleráveis: um consiste em subsumir o específico no genérico, mutilando o texto constitucional, e esta foi a via eleita pelo projeto de alteração do Regimento; o outro seria o caminho inverso, o do esvaziamento da norma genérica, até torná-la gratuita ou inoperante.

Ora, não há qualquer dificuldade, a meu ver, ante a clareza do elenco constante do $\S 2 .^{\circ}$ do art. 31 , em determinar-se quais as sessões do Congresso Nacional que, nos têrmos da Constituição, foram taxativamente confiadas à direção da Mesa do Senado, com a conclusão imperativa de que, em tais casos, não pode subsistir, nem prevalecer, a atribuição genèricamente outorgada ao Vice-Presidente da República. Se êste fôsse armado de poderes, além dos que the remanescem, por fôrça da ressalva contida no preceito específico, haveria, sem sombra de dúvida, delegação de poderes, que a Carta Maior veda e fulmina, em dois artigos que se completam: art. $6 .^{\circ}$, parágrafo único, e art. 55, parágrafo único.

Dir-se-á que o disposto no $\S 2 .^{\circ}$ do art. 31 tem tamanha amplitude que nada restaria ao Vice-Presidente da República, tornando-se letra morta o estatuído no $\S 2 .^{\circ}$ do art. 79. Veremos que não é assim, e que as funções remanescentes são as que se compadecem com a estrutura e o espírito do regime.

Antes, porém, de examinar êsse aspecto da questão, torna-se necessário focalizar o papel da Mesa do Senado e, em particular, o de seu Presidente, no contexto do ordenamento constitucional, pois é tão-sòmente nesta análise que poderão ser definidos, de maneira objetiva, os limites da competência do Vice-Presidente da República com relação ao Congresso Nacional, demonstrando-se que os dois dispositivos constitucionais são entre si compati- 
veis, não envolvendo qualquer antinomia, desde que se apliquem ambos simultâneamente, cada qual na esfera de sua respectiva incidência.

7. Se a análise "tópica" dos artigos 31 e 79 já nos revela qual o seu significado, êste resulta ainda mais nítido à luz de sua compreensão no sistema da Constituição de 1967.

Basta a leitura dos artigos $47,52,62, \S \S 1 .^{\circ}, 3 .^{\circ}, 4 .^{\circ} \mathrm{e}$ $5 .^{\circ}$, e $153, \S 2 .^{\circ}$, da Constituição, para verificar-se que em consonância com o disposto no $\S 2 .^{\circ}$ do art. 31, naquela. iniliminável contigüidade lógica a que se refere RuI BARBOSA - a Carta Magna assegura ao Presidente do Senado um status jurídico de contornos precisos.

É êle, em verdade, quem, "ex vi" dos citados preceitos,

a) recebe do Presidente da República a comunicação do veto por êle apôsto aos projetos de lei;

b) convoca as duas Câmaras para, em sessão conjunta, conhecer do veto;

c) promulga a lei, quando, rejeitado o veto, o Presidente da República deixa de fazê-lo dentro de quarenta e oito horas;

d) promulga a lei aprovada pelo Congresso $\mathrm{Na}$ cional nos têrmos do art. 47 da Constituição;

e) convoca o Congresso Nacional para apreciar ato do Presidente da República prorrogando o estado de sítio.

Entra pelos olhos, se não toldados pela paixão política, que todos êsses dispositivos confirmam e reiteram a competência específica proclamada no $\S 20^{\circ}$ do art. 31, perfilando o Presidente do Senado como única autoridade munida da legítima representação do Poder Legislativo em tôdas as relações com o Poder Executivo que envolvam atos decisórios de sua estrita competência: cabe-lhe dar 
início aos trabalhos do Congresso, convocando-o, presidi-lo e, afinal, sancionar e publicar o que a Câmara e o Senado em conjunto deliberaram.

No entanto, se viesse a prevalecer a estranha construção jurídica consubstanciada no projeto de resolução submetido a meu exame, assistiríamos ao sacrifício da unidade e inteireza do processo legislativo, pela fratura da Mesa do Senado, pela postergação dos poderes do seu Presidente, e pela co-participação de uma autoridade estranha na elaboração das emendas constitucionais, das leis complementares e ordinárias, dos decretos legislativos, bem como no contrôle dos decretos-leis.

Figuremos, para que a imagem dê mais relêvo ao pretendido desmembramento do processo legislativo, como passariam a se desenrolar os trabalhos do Congresso, segundo o projetado esquema de alteração regimental:

Ato $1^{\circ}$ - O Presidente do Senado convoca o Congresso (Antes de fazê-lo, teria de consultar o Vice-Presidente da República sôbre o dia e a hora convenientes ao seu comparecimento...).

Ato $2 .^{\circ}$ - Reunido o Congresso, o Vice-Presidente da República assume a presidência da sessão e dirige os trabalhos, assessorado pela Mesa do Senado, à qual, por eufemismo, se dispensa o poder de "direção".

Ato $3 .^{\circ}$ - Concluída a votação, o Vice-Presidente da República retira-se do Plenário ou silencia e se omite, entrando novamente em cena o Presidente do Senado para promulgar a lei aprovada!

É evidente que essas idas e vindas não se compadecem com a dignidade do Poder Legislativo, nem são aceitáveis por quantos compreendam ser da essência do processo legislativo a unidade de seu desenvolvimento, de tal sorte que quem tem a atribuição expressa de convocar o Congresso e de promulgar a lei não pode ser alijado de 
seu status jurídico de órgão a que está afeta a direção do processo legislativo, o qual, nunca será demais acentuá-la, ganhou galas de princípio constitucional, de validade cogente em todos os planos institucionais do País, como o estatui o art. 13, n. ${ }^{\circ}$ III, da Constituição.

$\mathrm{O}$ ato de convocação de uma Assembléia não é dêsses que uma autoridade possa condignamente exercer, estando na dependência do beneplácito de outra: é ato que, por sua própria natureza, traduz a originariedade da competência e a autonomia de seu exercício. Quem convoca o Congresso tem já implícito o poder de dirigir-lhe os trabalhos, se o faz na qualidade de órgão constituído para seu funcionamento: se assim não fôsse, haveria "capitis diminutio" manifesta, ficando o Presidente do Senado reduzido a simples instrumento da manifestação de vontade de outrem, sem cuja presença a convocação seria inútil...

Por outro lado, quem promulga uma lei exerce o mais alto e decisivo dos atos de soberania, e não pratica mera exigência de valor extrínseco, como se se tratasse de um funcionário destinado a executar o querer de uma autoridade superior.

Como esclarece um dos mais notáveis mestres contemporâneos de Teoria do Estado, Aldo M. SANdulli, o ato de promulgação não é, consoante supunha uma velha teoria, simples exteriorização da vontade do Parlamento, mas representa, ao contrário, um ato constitucional de manifesto poder político, que pressupõe o exame da legitimidade do processo legislativo, significando a atestação pública e solene da verificada vontade legislativa, concluída com obediência dos trâmites regulamentares e dos imperativos constitucionais, para que possa ser posta a norma de direito com validade e eficácia, a fim de ser obedecida por seus destinatários, órgãos do Estado e particulares (Cfr. Novissimo Digesto Italiano, 1957, v. IX, "legge", p. 643 e segs.). 
Como se vê, o conteúdo mesmo do ato de promulgar já revela que, em se devendo proclamar a decisão de uma Assembléia, dando-se fôrça cogente ao por ela própria deliberado, tal ato não pode ser executado senão por seu Presidente: em suma, se os textos constitucionais cometem ao Presidente do Senado o poder-dever de promulgar as leis $e$ os atos normativos do Congresso, isto equivale a dizer que, em se tratando de processo legislativo, é êle e tão-sómente êle quem preside às respectivas sessões.

8. Ainda no concernente às correlações sistemáticas, cabe frisar que o $\S 5 .^{\circ}$ do artigo 62 reporta-se ao artigo 47 , dando o sentido do item $\mathrm{V}$ do art. $31, \S 2 .^{\circ}$, segundo o qual à Mesa do Senado, além das funções discriminadas nos itens anteriores, cabe "atender aos demais casos previstos nesta Constituição".

Com efeito, o art. $62, \S 5 .^{\circ}$, conferindo ao Presidente do Senado o pader-dever de promulgar a lei aprovada em votação final pelo Congresso, "nos casos do art. 47", deixa explícito que tudo que se refira "à competência exclusiva do Congresso Nacional" deve ser resolvido pelas duas Casas Legislativas sob a presidência e direção da Mesa do Senado, tendo como centro o seu Presidente.

A discriminação do que se contém no art. 47 fornecenos com segurança a "ratio legis" determinante dêsse preceito, que subtrai ao Vice-Presidente da República além do disposto nos números I a IV do $\S 2 .^{\circ}$ do art. 31 - a condução das atividades do Congresso tôda vez que êste se reunir para:

I - resolver definitivamente sôbre os tratados celebrados pelo Presidente da República;

II - autorizar o Presidente da República a declarar guerra e a fazer a paz; a permitir que fôrças estrangeiras transitem pelo território nacional ou nele permaneçam temporàriamente, nos casos previstos em lei complementar; 
III - autorizar o Presidente e o Vice-Presidente da República a se ausentarem do País;

IV - aprovar, ou suspenđer, a intervençāo federal ou o estado de sitio;

V - aprovar a incorporação ou desmembramento de áreas de Estados ou de Territórios;

VI - mudar temporàriamente a sua sede;

VII - fixar, de uma para a outra legislatura, a ajuda de custo dos membros do Congresso Nacional, assim como os subsídios dêstes e os do Presidente e Vice-Presidente da República;

VIII -- julgar as contas do Presidente da República.

Não é indispensável ser conhecedor de Direito Público para saber-se que tôda essa matéria culmina na promulgação de Decretos Legislativos. Donde se conclui, em abono do já dito anteriormente, que, quando o Congresso Nacional se reúne para exercer funções de ordem normativa, quer apreciando vetos do Executivo, quer emanando atos normativos próprios, fá-lo sob a presidência da Mesa do Senado.

III.

O problema em função do espírito da Constituição de 1967.

9. A razão das determinações supra lembradas liga-se à natureza mesma dos princípios políticos que informam o Estatuto constitucional vigente.

É sabido que a Constituição de 1967 marca uma inovação radical no concernente ao processo legislativo, que, "ad instar" do que ocorre em outras Constituições do $2 .^{\circ}$ pós-guerra, como as da França, da Itália e da Alemanha, 
distribui a tarefa legislativa - que antes era apanágio e prerrogativa das Assembléias - entre o Executivo e o Legislativo, reforçada sobremodo a posição do primeiro. Tal fenômeno, que resulta de circunstâncias peculiares ao nosso tempo, e cuja apreciação político-sociológica nos levaria muito fora dos objetivos dêste Parecer - mesmo porque já o fiz alhures, apontando os aspectos positivos e negativos dessa inevitável e necessária atualização do processo legislativo -, reflete-se na multiplicação dos instrumentos de realização da tarefa de legislar, abandonada a antiga e superada dicotomia entre "lei constitucional" e "lei ordinária".

0 art. 49 da Constituição, abrindo o leque do "processo legislativo" em nada menos de sete figuras de "atos normativos", é integrado pelos dispositivos seguintes, que traçam as linhas de competência do Legislativo e do Executivo, ao mesmo tempo que fixam as regras operacionais de um e de outro Poder em suas relações recíprocas.

Cabe, desde logo, observar que dos sete atos normativos apenas dois se exaurem na órbita do Legislativo, como assunto de sua competência exclusiva: os Decretos Legislativos e as Resoluções. Os demais cabem, concomitantemente, aos dois Poderes, reservada muito maior faculdade de iniciativa ao Presidente da República.

Não é apenas com referência à amplitude das competências que se põe em posição privilegiada o Executivo: é também no tocante ao mecanismo adotado no procedimento legislativo, quer pela possibilidade de leis delegadas, quer pela possibilidade de ser exigido pelo Presidente da República o pronunciamento do Congresso em prazos certos, sob pena de automática aprovação de seus projetos de lei.

Para os fins da presente Consulta bastará lembrar o que rezam o $\S 3 .^{\circ}$ do art. 54 e o art. 58 da Constituição: 
urgente a medida, poderá solicitar que a apreciação do projeto se faça em quarenta dias, em sessão conjunta do Congresso Nacional, na forma prevista neste artigo".

"Art. 58 - o Presidente da República, em casos de urgência ou de interêsse público relevante, e desde que não resulte aumento de despesa, poderá expedir decretos com fôrça de lei sôbre as seguintes matérias:

I - segurança nacional;

II - finanças públicas.

"Parágrafo único - Publicado o texto, que terá vigência imediata, o Congresso Nacional o aprovará ou rejeitará, dentro de sessenta dias, não podendo emendá-lo; se, nesse prazo, não houver deliberação, o texto será tido como aprovado"

Ante dispositivos dessa natureza, torna-se manifesta a razão política que levou o legislador constituinte a não confiar as "sessões de caráter legislativo" do Congresso Nacional à direção do Vice-Presidente da República, que é eleito concomitantemente com o Presidente da República, não por votos pessoais do povo, como nas Cartas anteriores, mas "ex vi" de simples registro de seu nome ao lado do candidato eleito (art. $79, \S 1^{\circ} .^{\circ}$ ).

Tôdas as analogias ou reminiscências que se fazem invocando-se as Constituições de 1891 e 1946 - e veremos que tais invocações pecam pela base - deixam de lado, com perigoso desprêzo, as características próprias do regime político que a nova Carta Maior consagra, raciocinando-se em têrmos de um processo legislativo uno, com a supremacia pelo menos nominal do Congresso.

A realidade político-legislativa agora é bem outra, não se admitindo que as funções legislativas e normativas do Congresso - reduzido em suas atribuições e em suas vias de ação - fiquem ainda mais vinculadas ao Executivo, 
pela presença de uma autoridade dêste Poder, que receberia, graças ao artifício de uma alteração regimental, uma competência que a Constituição, por amor ao princípio da divisão dos poderes, absolutamente não lhe outorga.

Tôda vez que, na história política, no entrechoque dos fatos e das idéias, se subtraem atribuições a um dos Poderes do Estado, é natural que haja mais zêlo e cuidado na salvaguarda de suas competências exclusivas ou próprias, interpretando-se antes os textos constitucionais no sentido da preservação das faculdades inerentes à autonomia do Poder, cujas atribuições se delimitaram, do que para ainda mais se acentuar a perda de suas prerrogativas.

Ao estudioso do Direito político não é dado raciocinar em têrmos de pessoas, movido pela imagem desta ou daquela autoridade, julgada incapaz, por sua formação moral e por amor aos princípios democráticos, de abusar de poderes que se lhe outorgarem, ao arrepio da Lei Maior. Se, como ponderei logo no início dêste Parecer, a interpretação das leis constitucionais é inseparável de seus ditames políticos, não pode passar despercebida ao intérprete a inadmissibilidade de uma exegese que, situada nas coordenadas do ordenamento político atual, poderá redundar na subordinação de um Poder a outro, visto existir um sistema de legislação vinculada a prazos fatais, sôbre cujo decurso deve vigilar, não uma autoridade do Executivo, interessado no projeto de Lei ou na confirmação de um Decreto-Lei, mas quem haja participado e tenha por missão específica participar do processo legislativo.

10. Verdade se diga que os responsáveis pelo projeto de Constituição elaborado pelo Govêrno anterior não quiseram subtrair ao Congresso Nacional o poder-dever de pronunciar-se, sob a direçâo de autoridade própria, quanto aos atos do Poder Executivo, e nem o quis o Congresso quando teve a oportunidade de manifestar-se sôbre a matéria, pois nenhuma das emendas apresentadas ao primitivo artigo $77, \S 2 .^{\circ}$ (correspondente ao atual $79, \S 2 .^{\circ}$ ), 
foi acolhida; e uma delas, a Emenda . $^{\circ} 521-5$, do Deputado Rui Santos, pretendia que se deferissem ao VicePresidente da República "as funções de Presidente do Senado".

A rejeição dessa emenda constitui um subsídio histórico relevante, porque traduz o firme propósito do legislador constituinte de manter distintas as duas faixas de competências, preservando-se íntegra a figura do Presidente do Senado, com o status jurídico que os demais preceitos do projeto já então configuravam e que o texto definitivo da Carta consagra.

Com essa discriminação de atribuições ficava respeitado, em sua essência e no plano da "praxis", o princípio da divisão dos poderes, que, apesar das transformações operadas no "processo legislativo", se quis por duas vêzes proclamar, uma, de maneira genérica, no art. $6 .^{\circ}$, parágrafo único, e outra de modo específico, no parágrafo único do art. 55, que assim reza:

"Não poderão ser objeto de delegação os atos da competência exclusiva do Congresso Nacional, bem assim os da competência privativa da Câmara dos Deputados ou do Senado Federal.."

Evidenciado, como me parece ter sido feito, que ao Presidente do Senado cabe a direção do Congresso Nacional, quando reunido para tarefas legislativas, a pretendida alteração do Regimento Comum importa, iniludivelmente, em delegação de poder eivada de inconstitucionalidade manifesta.

Nem se diga que o parágrafo único do art. 55 se inscreve num artigo pertinente à "delegação legislativa", pois o que se não permite seja objeto de Lei delegada, com mais razão se veda seja matéria de uma norma regimental: se é verdade, é verdade evidente, que o Congresso tem competência para legislar sob a direção de um de seus pares, a outorga dessa presidência a uma autoridade do 
Executivo consubstancia delegação de poder nula de pleno direito.

Acresce que, vindo a caber ao Vice-Presidente da República a direção das sessões de caráter legislativo, com voto de qualidade, o seu voto poderá decidir do destino de emendas à Constituição que exigem maioria absoluta "dos votos dos membros das duas Casas do Congresso" (art. 51) ou da confirmação de Decretos-Leis (art. 58), o que equivale a dizer que a delegação, obtida por via de preceito regimental, influiria indefinidamente em todo o processo legislativo.

11. A esta altura, impõe-se saber quais as atribuições. deferidas ao Vice-Presidente da República ao se lhe conferir o título de "Presidente do Congresso" com voto de qualidade.

Não há dúvida que o texto do artigo $79, \S 2 .^{\circ}$, poderia ter sido mais claro, mas, situado no contexto do ordenamento, não é difícil apreender-lhe o real significado, que é e só pode ser o que resulta objetivamente da lei $e$ não de supostas intenções dos legisladores, cuja invocação seria de um anacronismo científico deveras alarmante.

Ora, o art. $79, \S 2 .^{\circ}$, só ficaria sem aplicação prática se o Congresso Nacional se instalasse apenas e tão-sòmente para fins de processo legislativo. Nada impede que as duas Casas se reúnam para atender a outros objetivos, que não os previstos no $\S 2 .^{\circ}$ do art. 31, sendo impossível excluir, "a priori", outras hipóteses de sessões conjuntas capazes de ensejar votação a ser dirimida graças a voto de qualidade, sem falar nas "sessões solenes", destinadas a homenagear chefes de Estado estrangeiros, a que refere o $\S 10^{\circ}$ do art. $10^{\circ}$ do atual Regimento Comum (Resolução n. ${ }^{\circ}$, de 1951, do Congresso Nacional).

A função política do Parlamento no mundo contemporâneo é de tamanha amplitude que - abstração feita dos atos de natureza normativa, de que tratam os artigos 47 e $31, \S 2 .^{\circ}$ - fácil é perceber quão vasto é o campo 
de ação que se entreabre ao Presidente do Congresso, no desempenho dos encargos comuns aos dois ramos do Legislativo, implicando a necessidade de reuniões conjuntas de deputados e senadores, bem como a constituição de órgãos técnicos comuns que assessorem aos representantes do povo, tal como ocorre nos Estados Unidos e na Europa.

O que o art. $79, \S 20^{\circ}$, prevê é que se, em tais circunstâncias, ocorrer empate na votação, caberá ao Vice-Presidente da República o voto de Minerva, mas sem, evidentemente, daquela previsão genérica defluir que, para que se amiúdem as possibilidades de desempate, lhe sejam cometidas atribuições que lhe não cabem.

Alegar-se-á que não serão freqüentes as oportunidades que terá o Vice-Presidente da República de agir em função do título que lhe foi conferido, mas ainda que assim fôsse - não haveria razão suficiente para dobrar as linhas das competências constitucionais, permitindo que um órgão do Executivo passasse a ser árbitro do destino do Congresso em sua missão específica de legislar.

Deve-se lembrar, outrossim, que o $\S 2 .^{\circ}$ do art. 79 abre a possibilidade de serem exercidas pelo Vice-Presidente da República "outras atribuições que lhe forem conferidas em lei complementar", de tal modo que possa ser mais que uma autoridade auxiliar ou de funções supletivas, apesar de sua vinculação originária e automática à sorte de seu companheiro de candidatura.

O simples fato, aliás, de no art. 79 , $\S 2 .^{\circ}$, estar prevista a eventualidade de outras funções significa, sem dúvida, que inexiste na lei o propósito de investir o VicePresidente da República do pleno e total exercício das atribuições de Presidente do Congresso, de per si já bastantes.

Em verdade, se sôbre os ombros do Vice-Presidente da República pesassem todos os encargos e responsabilidades pertinentes ao Congresso Nacional, teria porventura passado pela mente do legislador constituinte a preocupação de arranjar-lhe outras ocupações? 
O que se quis, em última análise, foi conferir uma tarefa ao Vice-Presidente da República, desde que não comprometesse de vez o princípio da divisão dos poderes. Não é de hoje, aliás, que a figura do Vice-Presidente da República está às voltas com o problema da falta de uma atividade permanente. Sabem-no todos que foi exatamente para contornar êsse impasse, como que inerente ao cargo, que os fundadores da Democracia norte-americana lhe deferiram a incumbência de presidir o Senado, o que não foi acolhido sem forte oposição, como lembra HERman PritchetT:

"The committee of eleven proposed that the Vice-President be available for this purpose (isto é, para substituir o Chefe da Nação em caso de morte, impedimento, etc.) and also made him ex officio president of the Senate. This latter arrangement caused a debate on September 7. Gerry and Mason thought this was an improper mixture of legislative and executive.

"But Sherman pointed out that "if the VicePresident were not to be President of the Senate, he would be without employment". (.. .)

The Senate has for its presiding officer the Vice-President. When serving in this capacity his title is President of the Senate. He has no vote except in case of a tie (Art. I, sec. 3). Giving the Vice-President this function in the Senate is a clear defiance of the principle of separation of powers, but the framers apparently concluded that this was the only way to give the Vice-President a useful occupation". (The American Constitution, 1959, p. 27 e 186).

Tais palavras evidenciam não só as limitações funcionais de um cargo de caráter essencialmente supletivo, como a tolerância havida, nos Estados Unidos da América, 
ao atribuir-se ao Vice-Presidente da República a direção dos trabalhos do Senado, com plena consciência de estar-se optando por uma via de exceção, em "um claro desafio" ("a clear defiance") ao princípio da divisão dos poderes.

Na história do presidencialismo yankee jamais desapareceu essa natural reserva ao "arrangement" de Filadélfia, tanto assim que veio cada vez mais se acentuando a praxe de o Senado ser, normalmente, dirigido por um senador eleito "pro tempore", consoante previsto no Artigo 1. $^{\circ}$, Secção $3, \mathrm{n}^{\circ}$, 6 , da Constituição norte-americana.

São concordes os tratadistas do presidencialismo norteamericano em reconhecer o caráter excepcional - e, por conseguinte, de interpretação estrita - da solução dada ao caso do Vice-Presidente, apesar de circunscrita apenas a uma das Casas do Congresso.

O eminente William Bennett Munro afirma peremtòriamente que o Vice-Presidente da República é um corpo estranho ou "um de fora" no seio do Senado, não participando da formação das Comissões permanentes e só dispondo de poderes perfuntórios ou de somenos:

"So they made him presiding officer of the Senate. But he is an outsider there, has no vote except in case of a tie, appoints no committees, and has nothing more than perfunctory powers. Theodore Roosevelt, when he held the post of VicePresident, referred to it as "a office unique in its functions, or rather in its lack of functions" (The Government of the United States, N. York, 1947, p. 169).

No sentido da excepcionalidade da mesma função manifesta-se também Bernard Schwartz, que salienta serem as Comissões permanentes "a parte vital dos trabalhos das duas Câmaras", compreendendo-se, assim, todo o alcance da exclusão do Vice-Presidente da República da constituição daqueles órgãos, cuja função, como já o salien- 
tava o mestre Woonrow WiLson, consiste em dar origem e em conduzir a obra legislativa. (Cfr. Schwartz - American Constitucional Law, Cambridge, 1955, págs. 51 e 62; Wilson - Congressional Government, $10 .^{\text {a }}$ ed., 1894, pág. 122).

O fato, pois, de a Constituição norte-americana declarar, incisivamente, no Art. $1 .^{\circ}$, Secção 3, n. $^{\circ} 4$, que o Vice-Presidente da República "shall be President of Seniate", nem por isso os mentores do presidencialismo yankee se deixaram levar pela fôrça aparente das palavras, olvidando a natureza excepcional daquela atribuição, interpretando-a sempre restritivamente, nos limites do princípio da divisão dos poderes.

No Brasil, ao contrário, onde não raro se dá mais valor à pompa dos títulos do que à substância das idéias e dos princípios, quer-se entregar ao Vice-Presidente da República a direção do Congresso Nacional, na plenitude de sua tarefa legislativa. .

O mais curioso é que, para tanto, invoca-se a história do Direito Constitucional pátrio, que não ampara, absolutamente, essa tese.

IV.

\section{O problema na tradição do Direito Nacional.}

12. Pelo que tenho lido, a começar pela justificação oferecida à projetada alteração do Regimento Comum, os defensores da extensão dos poderes do Vice-Presidente da República colocam de maneira falha os dados do problema, à luz da história constitucional brasileira.

É sabido que a Constituição de 1891 obedeceu ao modêlo norte-americano, tornando o Vice-Presidente da República "Presidente do Senado", sem declarar a quem caberia a presidência do Congresso, de sorte que o assunto foi transferido para o plano regimental. 
Não se punha, então, o problema como sendo da mais alta relevância, como acontece hoje em dia, pela razão óbvia de que o processo legislativo jamais se processava em Casas reunidas: os vetos apostos pelo Presidente da República aos projetos de lei, por exemplo, eram apreciados e votados separadamente, no Senado e na Câmara. (Constituição de 1891, art. 37, $\S 3 .^{\circ}$ ).

Reduzidas eram as funções do Congresso, no sistema de 1891, como o salientava Carlos Maximiliano:

"Reúne-se hoje todo o Congresso em uma sala, sòmente para abrir ou encerrar a sessão ordinária ou extraordinária, apurar a eleição de Presidente e Vice-Presidente da República e receber compromisso prestado por estas autoridades.

Nessas reuniões se não ventilam assuntos alheios ao seu objeto, nem sequer a Mesa põe a votos moções de aplausos ou congratulações não referentes ao pleito cujo resultado se discute".

"Se sobrevem assunto urgente, separam-se as duas Casas do parlamento, para deliberar em separado. Concluída a tarefa inadiável, reúnem-se de nôvo e retomam o trabalho interrompido. A razão é óbvia: interpretam-se restritivamente as leis ou preceitos derrogatórios do Direito comum". (Comentários à Constituição Brasileira, Rio, 1923, 2. ${ }^{a}$ ed., p. 294 e segs.).

Pois bem, no silêncio da Constituição quanto à prestdência do Congresso Nacional, os legisladores pátrios conscientes da excepcionalidade da função cometida ao Presidente da República, tal como ocorreu na Democracia do Norte - , ao elaborarem o primeiro Regimento Comum, em 1892, conferiram ao Vice-Presidente do Senado a presidência do Congresso.

É absurdo querer explicar-se o disposto no Regimento de 1892 com a alegação de que assim se fazia pela razão 
contingente de achar-se vago o cargo de Vice-Presidente, em virtude da renúncia do Marechal Deodoro da Fonseca, pois, em 1903, ao proceder-se à revisão da lei interna das duas Casas legislativas, aquêle mesmo princípio se consagrou, por amor aos principios e à pureza do regime.

É com êsse espírito que deve ser lido o comentário feito por Carlos Maximiliano ao artigo 44 da Carta de 1891, que dispõe sôbre o compromisso do Presidente da República:

"A Constituição Brasileira prevê tudo: achando-se funcionando as câmaras, fundem-se em Congresso, cujo Presidente, que é o Vice-Presidente do Senado, recebe a afirmação prevista pelo art. 44". (Comentários, cit. p. 470).

Fôrça é concluir que, durante quase quarenta anos, de 1891 a 1930, mesmo quando o Congresso Nacional tinha funções limitadas, sem qualquer interferência no processo legislativo, não admitiram os fundadores da Repúlica que fôsse êle presidido por um membro do Poder Executivo, mantendo-o confinado ao âmbito do Senado, não sem reservas, como se depreende do comentário de um dos mais abalizados constitucionalistas pátrios, JoÃo BarbalHo:

“ $€$ incontestável que um presidente eleito pelos senadores de entre si tem muito mais autoridade e fica com sua missão muito mais facilitada, como primus inter pares, do que um estranho à corporação. Durante todo o primeiro período presidencial não tivemos o Senado sob a presidência de seu vice-presidente, sem que inconveniente algum se produzisse? E a experiência a ensinar que o Senado dispensa bem o ser dirigido em seus trabalhos por quem não pertence ao seu grêmio". (Constituiçâo Federal Brasileira, Comentários, Rio, 1902, art. 32, p. 96). 
Eis aí uma lição que devia ser lembrada na presente conjuntura.

13. O ensinamento de BarbalHo e de outros mestres de nosso Direito Público repercutiu na Assembléia Constituinte de 1934, com a supressão do cargo de Vice-Presidente da República: em caso de vaga do cargo de Presidente da República, devia-se proceder a eleição, direta ou indireta, conforme o tempo decorrido (art. 51, $\S 3 .^{\circ}$ ), cabendo a substituição, nas hipóteses do $\S 8 .^{\circ}$, ao Presidente da Câmara dos Deputados, ao do Senado e ao da Côrte Suprema.

Na Constituição de 1937 não se restabeleceu o cargo de Vice-Presidente da República, o que só se deu com a de 1946, quando lhe foi novamente cometida a função de Presidente do Senado (art. 61).

Como nenhuma norma constitucional se referisse à figura do Presidente do Congresso, a questão foi, mais uma vez, transferida para a tela regulamentar.

Cabe aqui, desde logo, uma pergunta: podiam os nossos legisladores, por amor ao princípio da divisão dos Poderes, seguir o exemplo dos aplicadores da Constituição de 1891, atribuindo a direção do Congresso ao Vice-Presidente do Senado?

Tentou-se fazê-lo, mas não havia senão cumprir o estatuído no artigo 41 da Carta Magna, a saber:

"Artigo 41 - A Câmara dos Deputados e o Senado, sob a direção da mesa dêste, reunir-se-ão em sessão conjunta para:

I - inaugurar a sessão legislativa;

II - elaborar o regimento comum;

III - receber o compromisso do Presidente do Vice-Presidente da República;

IV - deliberar sôbre o veto". 
Idêntico dispositivo já figurava, como art. 28, na Constituição de 1934, razão pela qual Themistocles Cavalcanti observou:

"Preside à reunião (do Congresso) a mesa da Câmara alta, o Senado, de categoria mais elevada na hierarquia das câmaras legislativas. E, aliás, $a$ tradição do nosso Direito Constitucional, o consagrado expressamente no artigo 28 da Constituição de 1934". (A Constituição Federal Comentada, Rio, 1948, v. II, art. 41, p. 27).

Pois bem, foi em virtude dêsse imperativo constitucional que, pela Resolução n. ${ }^{\circ} 1$, de 20 de abril de 1951, o Congresso Nacional alterou o Reginento Comum - declarando competir a direção dos trabalhos à Mesa do Senado (art. 3..$^{\circ}$ : o Regimento limitava-se a reproduzir o preceito constitucional.

Como se vê, o Vice-Presidente da República não passou a presidir às sessões do Congresso por ser "Presidente do Congresso" - título que jamais lhe foi conferido -, mas tão-sòmente como decorrência do fato de integrar a Mesa do Senado como seu Presidente. A prova insofismável dêste entendimento têmo-la na própria Resolução n. ${ }^{\circ}$, de 1951, que foi promulgada pelo então Vice-Presidente Joño CAfÉ FILHo, o qual teve o cuidado de assinar o ato declinando a sua qualidade de Presidente do Senado Federal.

Não se considerou o ilustre e experimentado parlamentar, alçado depois à Suprema Magistratura do País, em condições de, no ato solene de baixar o Regimento Comum a ambas as Casas, atribuir-se o título de "Presidente do Congresso Nacional": tinha plena convicção de que a direção dos trabalhos comuns era mero "consecutivum" de sua condição de Presidente do Senado, consoante previsto no artigo 41 da Constituição de 1946.

Por fim, se lembrarmos que a Emenda Parlamentarista, de 2 de setembro de 1961, suprimiu, mais uma vez, 
0 cargo de Vice-Presidente da República, e que, ao ser restabelecido o sistema presidencial pela Emenda Constitucional $\mathrm{n}^{\circ} 6$, de 23 de janeiro de 1963, não se restituíram àquela autoridade as funções de Presidente do Senado; se atentarmos que foi essa a única ressalva feita então ao restabelecimento da Constituição de 1946, teremos uma visão histórica completa do problema, assinalando uma constante em nossa vida republicana, no sentido, ou de suprimir a intromissão do Executivo na órbita do Legislativo. ou de reduzi-la ao estritamente consignado na Constituição.

Diante disto e depois disto, como afirmar-se que a presidência do Congresso cabe ao Vice-Presidente da República, na tradição do Direito Constitucional brasileiro? Como sustentar-se semelhante tese, se, nos decorridos 76 anos de vida republicana, durante apenas 10 anos o VicePresidente exerceu aquelas funções, ciente e consciente de fazê-lo pela simples razão de ser membro da Mesa do Senado?

Não creio seja necessário acrescentar outras considerações para concluir - não sem observar, a esta altura, que o art. 41 da Constituição de 1946 corresponde, "mutatis mutandis", ao $\S 2 .^{\circ}$ do art. 31 da Constituição ora em vigor - que o título de "Presidente do Congresso Nacional", conferido ao Vice-Presidente da República, é uma novidade de 1967, que deve ser interpretada e situada sem ofensa à independência do Poder Legislativo e com zêlo pelo princípio da divisão das competências soberanas.

Ao contrário do que se alega, os artigos 31 , $2^{\circ}$, e 79 , § $2 .^{\circ}$, não se conflitam ou se repelem, se postos devidamente no contexto do ordenamento constitucional, significando uma clara discriminação que, como diria Gustavo RADBRUCH, resulta da "natureza das coisas"

Nem há razão para reclamar-se a revisão constitucional para resolver-se um conflito inexistente. Seria por demais melancólico, a esta altura do processo democrático 
nacional, que se reformasse a constituição para fortalecer o Vice-Presidente da República e, com êle, ainda mais o Poder Executivo, em detrimento da auto-organização e da autodeterminação do Congresso, ou, então, para confirmar o que já se mostra evidente nos textos em vigor quanto à competência da Mesa do Senado para presidir e dirigir os trabalhos legislativos comuns.

E o meu parecer, s. m. j.

São Paulo, 17 de abril de 1967. 